\title{
Biodiversity generation and loss
}

Book or Report Section

Accepted Version

Oliver, T. H. (2018) Biodiversity generation and loss. In:

Oxford Research Encyclopedia of Environmental Science.

Oxford University Press. doi:

https://doi.org/10.1093/acrefore/9780199389414.013.96

Available at http://centaur.reading.ac.uk/84169/

It is advisable to refer to the publisher's version if you intend to cite from the work. See Guidance on citing.

Published version at:

https://oxfordre.com/environmentalscience/view/10.1093/acrefore/9780199389414.001.0001/acrefore-

9780199389414-e-96

To link to this article DOI:

http://dx.doi.org/10.1093/acrefore/9780199389414.013.96

Publisher: Oxford University Press

All outputs in CentAUR are protected by Intellectual Property Rights law, including copyright law. Copyright and IPR is retained by the creators or other copyright holders. Terms and conditions for use of this material are defined in the End User Agreement. 


\section{www.reading.ac.uk/centaur}

\section{CentAUR}

Central Archive at the University of Reading

Reading's research outputs online 


\title{
Biodiversity Generation and Loss
}

\author{
T.H. Oliver ${ }^{1}$
}

${ }^{1}$ School of Biological Sciences, University of Reading, Whiteknights campus, Reading, UK, RG6 6AS; email:t.oliver@ reading.ac.uk

\section{Summary}

Human activities in the Anthropocene are influencing the twin processes of biodiversity generation and loss in complex ways that threaten the maintenance of biodiversity levels which underpin human well-being. Yet, many scientists and practitioners still present a simplistic view of biodiversity as a static stock, rather than determined by a dynamic interplay of feedback processes that are affected by anthropogenic drivers. Biodiversity describes the variety of life on earth, from the genes within an organism, to ecosystem level. However, this article focusses on variation amongst living organisms, both within- and between- species. Within species, biodiversity is reflected in genetic, and consequent phenotypic variation between individuals. Genetic diversity is generated by germ line mutations, genetic recombination during sexual reproduction and immigration of new genotypes into populations. Across species, biodiversity is reflected in the numbers of different species present and also, by some metrics, in the evenness of their relative abundances. At this level, biodiversity is generated by processes of speciation and immigration of new species into an area. Anthropogenic drivers affect all these biodiversity generation processes, whilst the levels of genetic diversity can also feedback and affect the level of species diversity, and vice versa. Therefore, biodiversity maintenance is a complex balance of processes and the biodiversity levels at any point in time may not be at equilibrium.

A major concern for humans is that our activities are driving rapid losses of biodiversity, which outweigh by orders of magnitude the processes of biodiversity generation. A wide range of species and genetic diversity could be necessary for the provision of ecosystem functions and services (for definition see Braat 2016); for example in maintaining the nutrient cycling, plant productivity, pollination and pest control that underpin crop production. The importance of biodiversity becomes particularly marked over longer time periods and in particular under varying environmental conditions. 
In terms of biodiversity losses, there are natural processes that cause roughly continuous low level losses, but there is also strong evidence from fossil records for transient events in which exceptionally large losses of biodiversity have occurred. These major extinction episodes are thought to have been caused by various large-scale environmental perturbations such as volcanic eruptions, sea level falls, climatic changes and asteroid impacts. From all these events, biodiversity has shown recovery over subsequent calmer periods, although the composition of higher level evolutionary taxa can be significantly altered. In the modern era, biodiversity appears to be undergoing another mass extinction event, driven by large-scale human impacts. The primary mechanisms of biodiversity loss caused by humans vary over time and by geographic region but include: overexploitation, habitat loss, climate change, pollution (e.g. nitrogen deposition) and the introduction of non-native species. It is worth noting that human activities may also lead to increases in biodiversity in some areas through species introductions and climatic changes, although these overall increases in species richness may come at the cost of loss of native species and with uncertain effects on ecosystem service delivery. Genetic diversity is also affected by human activities, with many examples of erosion of diversity through crop and livestock breeding or through the decline in abundance of wild species populations. Significant future challenges are to develop better ways to monitor both the drivers of biodiversity loss and biodiversity levels themselves, making use of new technologies, and improving coverage across geographic regions and taxonomic scope. Rather than treating biodiversity as a simple stock at equilibrium, developing a deeper understanding of the complex interactions - between environmental drivers, and between genetic and species diversity - is essential to manage and maintain the benefits that biodiversity delivers to humans, and to safeguard the intrinsic value of the Earth's biodiversity for future generations.

Keywords: Species diversity, genetic diversity, extinction, population decline, speciation, mutation, gene flow, population immigration, ecosystem services, natural capital stocks

\section{The need to understand biodiversity loss}

Ever since the expansion of early humans across the planet, biodiversity has been impacted by our activities, although the scales of impact and the primary mechanisms of action are changing over time. In the early $21^{\text {st }}$ Century, impacts are now so extensive that humans are presiding over a planetary scale re-assortment of species and over substantial losses such that many refer to the Anthropocene period as the Earth's sixth mass extinction event (Barnosky 
et al. 2011). International policy initiatives such as the Convention for Biodiversity (CBD 2010) have failed to halt the loss of biodiversity. Yet, many recent environmental studies suggest that devising appropriate strategies to maintain biodiversity levels will be crucial for maintaining human well-being in the future. As a consequence, a new paradigm in environmental management, spanning both the social and natural sciences, has emerged around the concept of natural capital accounting, where biodiversity is viewed as a 'natural capital stock' underpinning the flow of ecosystem services (Monfreda et al. 2004; Jones 2010; Kareiva et al. 2011; Christian 2014; Helfenstein \& Kienast 2014; Remme et al. 2016). This may increase the visibility of biodiversity in mainstream economic decisions, but a concurrent danger is that this framing ignores the highly dynamic and complex nature of biodiversity. In this article, this dynamism and complexity is explored along with the varied processes responsible for the generation and loss of biodiversity. These processes include both natural 'background' rates of biodiversity change that have operated in the absence of humans, and also the substantial interventions into these processes by human activities. Biodiversity is considered at both the genetic and species level, as well as the interactions between these levels. The overarching aim is to develop a better understanding of the complex processes that influence the balance between biodiversity generation and loss and which ultimately determine the maintenance of biodiversity levels. The topic is important because these biodiversity levels in turn influence the delivery and resilience of ecosystem services for humans. The work draws on paleoecological and contemporary ecological research, and provides a more nuanced view of biodiversity 'stocks' that will hopefully contribute to broader environmental management studies.

\section{What is biodiversity and how is it measured?}

Biodiversity describes the variety of life on earth, from the genes within an organism, right up to ecosystem level. The Convention for Biological Diversity (CBD 1992) defines biodiversity as "the variability among living organisms from all sources including, inter alia, terrestrial, marine and other aquatic ecosystems and the ecological complexes of which they are part; this includes diversity within species, between species and of ecosystems". This review article focusses primarily on biodiversity at the level of genes and species, rather than ecosystems. This is partly due to space constraints, but also because the methods to quantify biodiversity at these levels of the hierarchy are better developed than at the ecosystem level. Many articles focus exclusively on either genetic or species-level diversity but fail to consider the relationships between the two. Here, a more integrated approach is adopted in 
the hope that it leads towards a fuller and more holistic understanding of the implications of biodiversity loss.

\section{What is Species diversity?}

Species diversity reflects the number and proportional abundance of species in a given community. It is important to note that our estimates of species diversity often come from samples which are assumed to reflect true levels of overall diversity, but which will nearly always be imperfect or biased to some degree (Magurran 1988). The most commonly used metric is species richness, simply reflecting the number of unique species. However, two communities can have the same number of species, but one may be more diverse because it is more balanced in terms of species' relative abundances, whilst in the other community some species are very dominant and others rare (Figure 1). Therefore, a number of diversity metrics have been developed to account for this, including the Shannon-Weiner Index and the GiniSimpson index. There are a large number of such diversity metrics, each capturing slightly differently the components of richness and dominance (Pielou 1975; Magurran 1988; Magurran 2004). Rather than treating each species as equal, other extensions of diversity metrics have also been developed which weight differences between species with respect to ecological function or phylogenetic uniqueness. Functional diversity measures quantify the distribution of traits in a community or the relative magnitude of species similarities and differences in those traits (Petchey et al. 2004; Villéger et al. 2008; Cadotte et al. 2011). Phylogenetic diversity captures the evolutionary distinctness between species in terms of the total length of branches separating them in a phylogenetic tree. There are many different proposed ways of calculating these metrics, some which also integrate species relative abundances (Rao 1982; Chao et al. 2010).

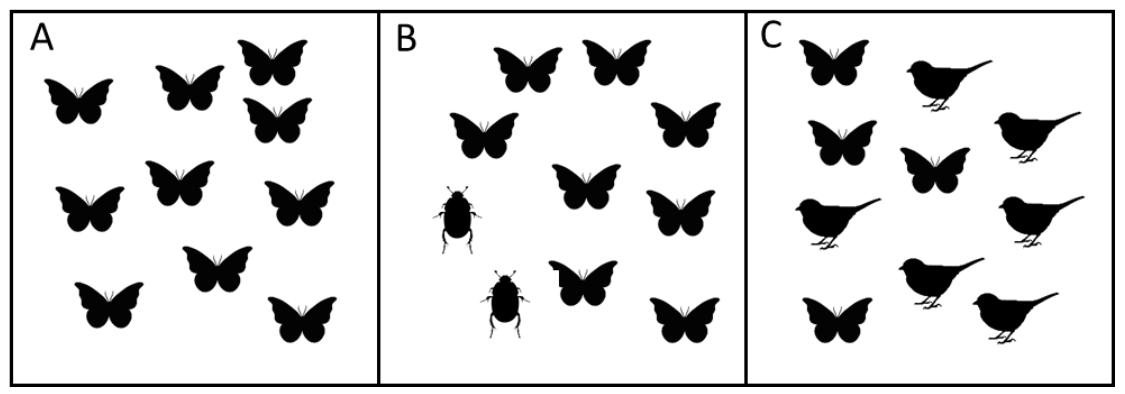

Figure 1, Schematic of three communities differing in species $\alpha$ diversity (species type indicated by filled shapes). Panel A has the lowest diversity, whilst panels B and C have 
equal species richness. However, panel $\mathrm{C}$ has a higher diversity measured by metrics which incorporate evenness in abundance, such as the Shannon-Wiener index or the Gini-Simpson index, and it also has higher phylogenetic diversity.

\section{What is Genetic diversity?}

Genetic diversity reflects the variation in genetic composition amongst individuals within a population. It can be measured in a number of ways, depending on whether the traits are coded for by discrete allelic states or by multiple loci ('quantitative' traits). In the former case, the simplest index is allelic richness, which reflects the number of different alleles for a given locus within a population. Allelic diversity extends this to combine information about the number and relative frequency of alleles per locus, in an equivalent way to the Shannon-

Weiner index of species diversity. Heterozygosity considers the probability that two randomly chosen alleles in a population are different, and is similar to a Gini-Simpson Index of species diversity (Magurran 2004). For quantitative traits, measures include the genetic variance, which is the variance in a phenotypic trait due to genetic differences (Hughes et al. 2008). In many cases, such variance is correlated arbitrarily with the trait mean value, and so the coefficient of genetic variance is used to correct for this allowing comparison between groups with different trait means.

\section{Scale of biodiversity measurement}

Both species and genetic diversity can be measured at different spatial or temporal scales. Diversity measurements for a given assemblage of species (e.g. at a certain location) are referred to as $\alpha$ (alpha) diversity (Whittaker 1972). The change in genetic or species composition between locations or over time can also be assessed, and this turnover in biodiversity is termed $\beta$ (beta) diversity. Finally, the overall measure of diversity across all communities in a larger geographic region is termed $\gamma$ (gamma) diversity. Biodiversity change is, therefore, multifaceted and complex; for example, $\alpha$ diversity may increase locally whilst simultaneously decreasing at the regional level due to homogenisation of species communities (i.e. reducing $\beta$ and $\gamma$ diversity).

\section{The maintenance of biodiversity levels}

To understand the maintenance of the 'stocks' of biodiversity that are available to deliver important ecosystem services which underpin human well-being (Folke 2016), we need to understand the balance between the multiple processes of biodiversity generation and loss 
and any interactions between genetic and species diversity. Being able to monitor and manage these biodiversity stock levels is critically important for ecosystem management, and it is part of the rapidly developing field of 'natural capital accounting' (Monfreda et al. 2004; Jones 2010; Kareiva et al. 2011; Christian 2014; Helfenstein \& Kienast 2014; Remme et al. 2016). However, there is a danger that the economic concept of 'natural capital stocks' ignores the highly dynamic and complex nature of biodiversity maintenance, in which internal system feedbacks are common. In addition to simply mapping and accounting for existing biodiversity levels, it is necessary to understand the processes that lead to biodiversity change in order to ensure that critical biodiversity levels are maintained in the future (Brand 2009; Barnosky et al. 2012; Steffen et al. 2015b). A number of studies have attempted to predict future states of global biodiversity, but they focus nearly exclusively on species richness and the extinction process (Sala et al. 2000; Pereira et al. 2010). Yet, human activities can affect both speciation and extinction (Bull \& Maron 2016), and there may be complex feedbacks between genetic and species diversity levels (Fig. 2). 


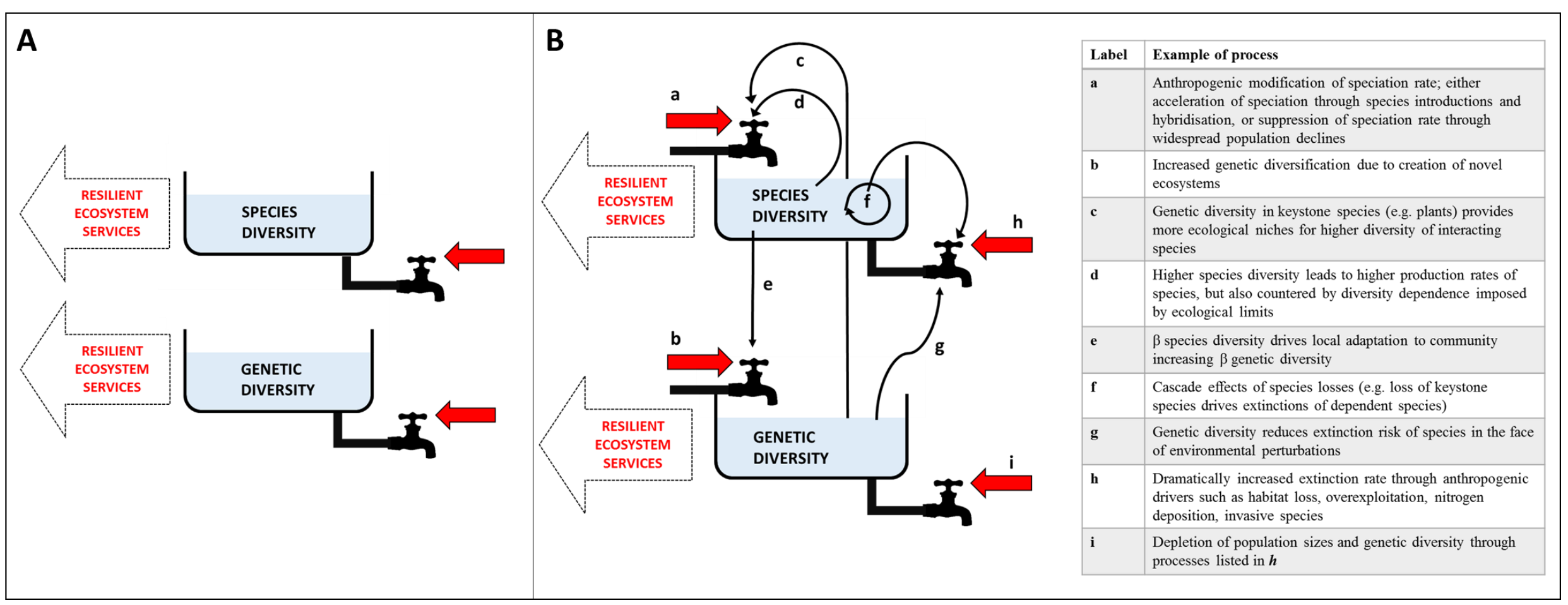

Fig. 2. Panel A shows a very basic conception of biodiversity stocks with reservoirs of species and genetic diversity (shaded areas in tanks) responsible for maintaining resilient delivery of ecosystem services. Anthropogenic actions (red arrows) are most often assumed to be reducing biodiversity stocks. This conception, however, ignores biodiversity generation processes (both anthropogenic and natural) and also ignores interactions between stocks of species and genetic diversity. Panel B is a schematic of the complex systemic relationship determining the maintenance of biodiversity levels. Ecosystem services depend upon stocks of species and genetic diversity, which are affected both by anthropogenic drivers (red arrows) and internal feedback processes (black arrows). Examples of mechanisms are provided in the table. See main text for further details and more examples. Note that the causal mechanisms shown in this figure are not exhaustive. 


\section{Processes of biodiversity generation}

\section{The generation of genetic diversity}

Genetic diversity is generated ultimately by germ-line mutations (i.e. in those cells which carry DNA to be passed on to future generations), involving the insertion, substitution or deletion of nucleotide bases during DNA replication (Pray 2008). Mutation rates per genome assessed in laboratory studies show similar rates within broad groups of organisms, but large differences among groups. For example, Drake et al. (1998) found rates of $3.33 \times 10^{-3}$ per genome per replication in microbes, $0.1-1$ for viruses, and $0.1-100$ per sexual generation in higher eukaryotes (but the same mutation rate as microbes per effective genome, which excludes the fraction of the genome in which most mutations are neutral). Many of these mutations in gene-coding regions of the genome are deleterious in that they reduce the fitness of the organism (i.e. its survival and/or chances of reproducing) and therefore they do not exist in a population for very long. Other mutations have neutral effects, especially if they occur in a gene whose function is required only rarely or is redundant, or in parts of the DNA that do not code for genes (such as introns and intergenic regions). A very few mutations have positive effects on the fitness of an individual and therefore will often tend to increase in frequency in a population.

In addition to the generation of new genetic diversity through mutation, in sexually reproducing organisms new combinations of genes arise through recombination. This process involves the exchange of genetic material between the maternal and paternal chromosomes during cell division to produce gametes (meiosis). Although not adding to the basic diversity of genes in a population, sexual selection leads to new combinations of genes that produce different phenotypes (measurable traits of an individual reflecting gene-environment interactions). The rates of innovation of new phenotypes arising from sexual reproduction are typically much higher than through mutation (Barrick \& Lenski 2013). This ability to generate new diversity has been suggested to partly explain the success of the strategy amongst eukaryotic organisms (Muller 1932; Crow 1994; Burt 2000; but see Gorelick \& Heng 2011), for example, increasing the capacity to evolve adaptations to resist parasites (Hamilton et al. 1990).

Genetic diversity provides the fuel for natural selection to drive changes in the traits of a population. This occurs through the biotic or abiotic environment imposing unequal fitness costs across the (genetically different) individuals of a population. The loss of individuals from a population then leads to erosion of this genetic diversity; although the particular type of natural selection can have different effects, which may be more or less temporary (Bulmer 
1971). Stabilising selection involves higher fitness for individuals with intermediate phenotypic trait values, leading to loss of individuals with genes coding for extreme phenotypes, and thus reducing genetic variance in a population. Diversifying selection, in contrast, involves higher fitness for individuals with both higher and lower phenotypic trait values and lower fitness for intermediate phenotypes, thus increasing genetic variation. Directional selection, involves a higher fitness for either high or low values of a trait, thus initially reducing genetic diversity but with potential recovery of genetic variance around higher or lower mean phenotypic trait values (Bulmer 1971).

The immigration of individuals into a population can also affect genetic diversity by introducing new genes into a population ('gene flow'; Slarkin 1985), which may increase in frequency if they increase individual fitness in the new environment. At the regional scale, however, gene flow can reduce $\beta$-diversity by reducing genetic differentiation between populations that would arise through local adaptation (Austerlitz et al. 2000; Lenormand 2002; but see Tigano \& Friesen 2016).

In summary, these combined processes: DNA mutation, recombination under sexual reproduction, and population-level migration all combine to generate genetic diversity within populations. In some cases, the resulting phenotypic variation in populations can be substantial even outweighing differences between species.

\section{The generation of species diversity}

New species are created through the process of speciation which involves evolution of reproductive isolation, i.e. genetically-based barriers to gene exchange, which typically involves initial spatial separation between different populations (Fitzpatrick et al. 2009; Schluter \& Pennell 2017). Whilst populations are separated, natural selection or genetic drift can lead to reproductive isolation, and even if the two lineages meet again in sympatry they will then most often continue to diverge in terms of genetic composition and phenotypes. Rates of diversification vary between species groups, with plants showing median rates of 0.06 new species per species per million years, 0.15 for birds, and 0.07 for mammals (Pimm et al. 2014). The rate of these speciation events are determined by the rate of evolution of reproductive isolation, which is in turn affected by standing genetic variation and the rate of new mutations (Schluter \& Conte 2009). Demographic and metapopulation processes play a role by affecting the likelihood of establishment of new populations, persistence rates of new populations, and rate of establishment of sympatry after reproductive isolation is complete (Schluter \& Pennell 2017). Because the physical and abiotic environment of populations 
influences these factors, there arises variation in speciation rates across geographic space as well as over evolutionary time. For example, there is a broad pattern of increased species diversity in lower latitudes, closer to the tropics, which is consistent across most species groups (Mittelbach et al. 2007), and some authors believe this may be partly driven by latitudinal gradients in extinction rates. Higher temperatures in the tropics may lead to higher metabolic rates in ectothermic species, shorter generation times and more rapid genetic divergence between populations. However, a number of studies contradict this claim, suggesting that speciation rates in groups such as birds and mammals could be highest in the temperate zone (Schluter \& Pennell 2017). However, this counter argument only holds for the speciation rate per species. Because there are many more species in the tropics the absolute rate of species production is thought to be higher in these locations (Schluter \& Pennell 2017). Some authors have speculated that speciation rate might decline at higher diversities as resources become depleted (the 'ecological controls' model; Rabosky \& Hurlbert 2015; Schluter \& Pennell 2017), whilst others have suggested that species themselves are resources that could speed up speciation rates (the 'diversity begets diversity' model; Whittaker 1977). These viewpoints can be partly reconciled by the consideration of non-linear relationships between speciation rate and number of existing species in a location. When there are only a relatively small number of species, speciation rates are high. However, as species numbers approach some carrying capacity, determined by the number of unoccupied ecological niches, the speciation rate slows and/or becomes matched by higher extinction rates. Thus, speciation rates show positive but saturating relationship with species number, analogous to density dependent population growth rates in single species (and so instead referred to as 'diversity dependence'; Marshall \& Quental 2016). A large number of studies support this diversity dependence hypothesis (Marshall \& Quental 2016); although it is increasingly recognised that carrying capacities can change through time (Ezard \& Purvis 2016; Marshall \& Quental 2016). For example, new evolutionary innovations in a clade, or changes to the environment can open up new resources, leading to sudden jumps in carrying capacity (Erwin 2012; Marshall \& Quental 2016). Some authors have also raised the point that in many cases species diversity may be well below carrying capacity for any meaningful diversity dependence to be imposed; for example, they point to how new introductions of species (e.g. through human-mediated invasion, or assisted colonisation), do not always cause extinction of local native species (Harmon \& Harrison 2015).

Although speciation is the ultimate driver of new species, the process of species immigration also influences the diversity of species in any given region, as demonstrated by 
MacArthur and Wilson in their studies on island biogeography (1967). They predicted that smaller and more isolated islands would have lower species richness, in part because they had lower rates of immigration, a prediction that is supported by some empirical studies, although since its inception, the theory has been further refined (e.g. Brown \& Kodric-Brown 1977; Gilbert 1980; Brown \& Lomolino 2000).

\section{Interactions between genetic and species diversity}

The interactions between genetic and species diversity are important because the impacts of an environmental driver can propagate across the hierarchical levels of biodiversity. In light of such dynamism many ecological systems may not be at equilibrium, thereby confounding the treatment of biodiversity as a simple standing stock.

With regards to the relationship between species richness and average genetic diversity within populations of those species, overall there appears to be a positive correlation. For example, Vellend and Geber (2005) analysed 17 datasets and found evidence of positive correlations, especially on island ecosystems. There are a number of possible mechanisms driving these correlations. First, both species diversity and genetic diversity may be affected by a shared driver, such as environmental heterogeneity. So, in the island systems considered by Vellend and Geber (2005), on larger islands there may be both a wider range of abiotic conditions and geographical features which separate populations, leading to higher species diversity (Stein et al. 2014) and larger genetic diversity through both local adaptation (Kawecki \& Ebert 2004) and genetic drift (Vellend \& Geber 2005). Beyond this indirect relationship driven by shared environmental drivers, genetic diversity can also have direct effects on species diversity. High genetic diversity can lead to lower extinction rates of species because adaptive genetic variance in a population increases the likelihood of population persistence under perturbations such as those caused by weather and disease (Reusch et al. 2005; Hughes et al. 2008; Sgrò et al. 2011; Forsman \& Wennersten 2015). Higher genetic diversity may also lead to greater stability in food webs (Moya-Laraño 2011). Furthermore, genetic variation in the keystone species of a community can provide more ecological niches for interacting species (Hersch-Green et al. 2011) and can drive diversifying selection on other species (Vellend \& Geber 2005). The relationship between species richness and genetic diversity can also operate in the reverse direction, whereby species diversity has direct effects on genetic diversity. For example, higher overall $(\gamma)$ species richness that is spatially structured (i.e. different communities in different locations) may lead to local adaption to competitors in each neighbourhood, thus increasing genetic 
diversity at the larger spatial scale (i.e. gamma genetic diversity; Vellend \& Geber 2005). However, an opposing mechanism may also operate if higher local species richness means that population sizes of each species are smaller (e.g. due to some kind of ceiling on the total number of individuals of all species in a community based on energy limitation); then genetic variability, which declines under small population sizes, could be lower (Vellend \& Geber 2005). However, this expectation does not match with the observed positive correlations between genetic and species diversity which is often observed (Vellend \& Geber 2005; Struebig et al. 2011).

\section{Modification of natural biodiversity generation processes by humans}

Anthropogenic drivers can interfere with biodiversity generation processes in a number of ways. For example, human activities are known to have strong impacts on evolutionary change in other species (Stockwell et al. ; Hendry et al. 2008), and may commonly affect speciation rates (Bull \& Maron 2016). Introduction of species to distant countries with very different environments, and little gene flow back to original populations, may lead to genetic divergence and ultimately speciation (Thomas 2013). Furthermore, high rates of hybridisation between introduced and native species may further accelerate this process. This has led to the provocative suggestion that human-induced speciation could result in a net increase in the number of species on Earth even whilst we are losing irreplaceable populations, races, species and evolutionarily distinct taxa (Thomas 2013; Thomas 2015). However, the proportion of hybrids that have resulted in speciation has yet to be adequately quantified (Mallet 2007; Abbott et al. 2013).

Domestication of plants and animals (e.g. crops, livestock and pets) can lead in some cases to populations which cannot interbreed and are effectively new species (Thomas 2015), as well as driving accelerated evolution in pests and diseases (Palumbi 2001; Gladieux et al. 2011). Novel ecosystems created by human activities (e.g. by altering land use and climate and through the introduction of new species) often lead to significant losses of species diversity (Butchart et al. 2010; Newbold et al. 2015), but in some cases there is evidence that the new introductions can offset species local extinctions (Mascaro et al. 2012; Vellend et al. 2013). These novel ecosystems also lead to significantly different abiotic and biotic evolutionary pressures on species, leading to trait changes in multiple interacting species (Palkovacs et al. 2012), and in some cases potentially driving speciation events (e.g. as shown in mosquitoes Byrne \& Nichols 1999). The large-scale alteration of landscapes through habitat fragmentation is well known to affect gene flow (Storfer et al. 2010). Habitat 
losses can lead to remaining patches becoming more isolated and suffering more from edge effects. Ultimately, this increased isolation has the potential to lead to genetic divergence into separate species, as suggested for a mesoamerican damselflies by Feindt et al (2014). With regards to future human impacts, emerging technologies such as genetic modification (Bull \& Maron 2016) and 'de-extinction' (Sherkow \& Greely 2013) could potentially lead to the generation of entities which are, technically, new species.

The processes detailed above are all speculated to lead to human-driven increases in speciation rates, but it is also possible that human activities could suppress natural speciation rates (Bull \& Maron 2016). The most obvious factor is the large reductions in average abundance of species that human activities cause, e.g. through habitat loss, overexploitation, nitrogen deposition and introduction of invasive species (Newbold et al. 2015; Newbold et al. 2016). This is likely to reduce the genetic diversity within species (Pichler \& Baker 2000; Allentoft \& O'Brien 2010a; Struebig et al. 2011), reducing the pool of standing adaptive genetic variation. Furthermore, these drivers can lead to the reduction in species' geographical ranges, leading to concurrent reductions in the likelihood of speciation (Rosenzweig 2001).

\section{Processes of biodiversity loss}

\section{Natural processes of biodiversity loss}

Biodiversity losses occur continuously even in the absence of human interventions. Natural and sexual selection lead to the loss of genetic adaptive variation, albeit if this is only temporary (Bulmer 1971). At the species level, the 'background' extinction rate of species (i.e. during periods outside mass extinction events) was once estimated to be about 1 extinction event per million species-years (E/MSY), but this has now been revised as being too high (Pimm et al. 2014). Alroy et al. (1996) found a rate of 0.17 extinctions of genera per million genera-years. Harnik et al. (2012) found a rate of 0.06 genera extinctions per million genera-years for cetaceans, 0.04 for marine carnivores, and 0.001 and 0.01 for a range of marine invertebrates.

During certain geological periods rates of biodiversity loss have vastly exceeded these background rates. Five particularly notable events are known as the five 'mass extinction' events. These events occurred in the Late Ordovician, Late Devonian (Frasnian-Famennian), Late Permian, Late Triassic and end-Cretaceous periods (Raup \& Sepkoski 1982; McGhee et al. 2004). The causes of these events are unclear, although all are associated with evidence for climatic changes, including both rapid global warming and cooling (Twitchett 2006). 
Other, non-mutually exclusive explanations are asteroid impact, ocean stagnation (reduced upwelling and loss of surface productivity), volcanic eruptions, catastrophic methane release and sea level changes. For example, an asteroid impact is thought to be largely responsible for the mass extinction event in the end-Cretaceous period around 66 million years ago. However, recent evidence suggests that dinosaurs may have been in decline, with speciation rates falling below extinction rates, for tens of millions of years before this final catastrophic event, although the cause for this is unknown (Sakamoto et al. 2016). The most severe event was the Late Permian event which saw around $62 \%$ of terrestrial and $48 \%$ of marine familylevel biodiversity wiped out (Benton 1995). From all these events, biodiversity has shown recovery over subsequent calmer periods, although the composition of higher-level evolutionary taxa can by altered significantly (Kauffman \& Harries 1996; Solé et al. 2002).

\section{Acceleration of biodiversity loss by humans}

Although loss of genetic diversity and extinction of species are natural phenomena, the activities of humans appear to have rapidly accelerated rates of biodiversity loss (Pimm et al. 2014). Current rates of rates of extinction may be over 1000 times the background rate of extinction (Pimm et al. 2014; Ceballos et al. 2015). Furthermore, many species are threatened with extinction in the near future. For example, nearly $32 \%$ of the world's amphibian species, and $22 \%$ of the world's mammal species are known to be threatened or already recently extinct (IUCN 2017). The likelihood of extinction depends on phylogeny and species traits, with much research aimed at attempting to understand which types of species are most vulnerable (McKinney 1997; Payne et al. 2016). For example, large bodied mammals and birds are about three times more likely to be threatened than small bodied species (Tilman et al. 2017), low-fertility preference plant species are more likely to be outcompeted under nitrogen deposition (Isbell et al. 2013), whilst in the marine environment calcifying reefforming corals are more likely to be threatened due to ocean acidification (Anthony et al. 2008). Across species groups, amphibians tend to be more threatened than mammals and reptiles, with birds showing lowest levels of threat; insects have generally been poorly studied, but recent estimates suggest high levels of decline (e.g. 33\% declining with an overall 45\% mean abundance decline; Dirzo et al. 2014). The patterns of threat to species also vary across geographic regions; for example $80 \%$ of amphibians are threatened or extinct in the Dominican Republic, Cuba, and Jamaica, and 92\% in Haiti (IUCN 2017). Areas with very high biodiversity (and large number of unique, endemic species) which also face high 
levels of threat have been identified as 'hotspots' for the focus of high priority conservation action (Myers et al. 2000).

Global extinctions of species are, however, only really the tip of the iceberg of humanmediated impacts on biodiversity. Species do not become extinct until all local populations are extirpated, so the rates of local species' population loss (affecting $\alpha$-diversity) can be many times higher than global extinction rate, potentially around three orders of magnitude higher (Hughes et al. 1997). From a recent analysis of hundreds of monitoring studies, Newbold et al. (2015) estimated average declines in population size of around $11 \%$ globally, and $39.5 \%$ in the worst affected habitats. A contrasting estimate from the WWF Living Planet Index (2016) puts the figure much higher at 58\% decline in population sizes in the last four decades. The discrepancy is at least partly to do with the different sampling regimes of the two studies, and the extent to which they are standardised to represent global land use or habitat distributions. The debate about the extent of local biodiversity change permeates much more widely in the ecological literature (Gonzalez et al. 2016; Isbell et al. 2017). Whilst many studies clearly show local loss of species diversity, for example, in areas converted to intensive cropland or pasture (Newbold et al. 2015), other studies suggest no net loss, or even increases in local species richness, mainly due to the introduction of new species from elsewhere (Sax \& Gaines ; Vellend et al. 2013). For example, Dornelas et al. (2014) analysed 100 time series across different global biomes and did not detect a systematic loss of $\alpha$-diversity. However, there were losses of $\beta$-diversity, potentially reflecting homogenisation of species communities. Even though $\alpha$-diversity may be stable in some cases, this does not mean we should not monitor and respond to the substantial community changes under anthropogenic drivers. Although the maintenance of total biodiversity levels is important, it is not the only relevant indicator for ecosystem management- the specific composition of these biological communities also affects the capacity to deliver ecosystem services (Lavorel \& Garnier 2002; Suding et al. 2008). High intensity anthropogenic land use tends to affect more habitat specialist species that may be of conservation concern (Warren et al. 2001). In some cases, rare species may be particularly important for ecosystem services (Mouillot et al. 2013; but see Kleijn et al. 2015). It is also questionable whether introduced species will be able to carry out the same ecosystem services as lost native species (Wardle et al. 2011; Oliver et al. 2015b). Homogenisation of biodiversity (i.e. reduction of $\beta$-diversity across sites) also has the potential to reduce the stability of ecosystem services at a regional scale (Wang \& Loreau 2014). 
In addition to, and partly caused by the loss of abundance, the genetic diversity of species' populations is also often eroded by anthropogenic activities, although this is more poorly studied and reported. Studies that have quantified genetic diversity have tended to be focus on livestock, crops or fisheries. For example, Smith et al. (1991) reported on significant losses of genetic diversity in orange roughy Hoplostethus atlanticus fish stocks through overfishing, especially through the loss of older and more heterozygous individuals. Similar losses in genetic diversity have been reported in New Zealand snapper Pagrus auratus (Hauser et al. 2002) and North Sea cod Gadus morhua and many other species (Allendorf et al. 2008; Pinsky \& Palumbi 2014), although genetic diversity recovered in the cod species after heavy overexploitation was halted allowing recovery of population levels (Hutchinson et al. 2003). Within terrestrial crop plants and livestock, although breeding and domestication has led to broader phenotypic differences between races (Thomas 2015), in many cases diverse native breeds are replaced by a small number of highly productive breeds (EEA 2015). In addition, for several species or breeds there is evidence that genetic diversity has declined over time (e.g. soybean, Hyten et al. 2006; and wheat, Bonnin et al. 2014), whilst in others it seems to have been retained (e.g. apples; Gross et al. 2014). In wild species, there are many studies considering spatial patterns and taxonomic patterns in genetic diversity (e.g. Garner et al. 2005; Allentoft \& O’Brien 2010b; Miraldo et al. 2016) but studies of trends over time are rare. Where studies exist, patterns are mixed; for example, genetic diversity in wild cheetah populations has declined over time (Terrell et al. 2016), whilst a long-term study in wild bumblebees suggested stability in genetic diversity over the last century (Maebe et al. 2016).

\section{The potential impacts of biodiversity loss for humans \\ Species diversity and ecosystem functions and services}

What are the potential consequences of the substantial species re-assortment and biodiversity losses now occurring in the Anthropocene? Human health and well-being is strongly dependent upon biological communities. Ecosystem services comprise the ways in which natural ecosystems meet the demand from human needs and wants, the benefits, and the various types of values to humans (Folke 2016). They include direct provisioning of food and building materials and regulatory processes such as climate regulation and pollination (Mace et al. 2012). In addition, species provide cultural services which underpin recreational, aesthetic and spiritual benefits of engaging with nature (Church \& et al. 2011; Clark et al. 2014). Even if not direct service providers themselves, many species provide supporting 
services, which means that other service-providing species depend upon them (e.g. by using them as food sources). Because of these extensive human dependencies on species, a loss of species diversity can mean negative impacts on prosperity, human health and well-being (Cardinale et al. 2012; Mace et al. 2012; Dirzo et al. 2014; Gascon et al. 2015). For example, many empirical studies have examined the relationship between species diversity and ecosystem functions. These ecosystem functions are the ecological processes that are precursors to the delivery of ecosystem services, the latter often additionally involving the contributions of work, technology, institutions, energy, and materials from the human system (Folke 2016). Much research in this area began by focusing on plant species diversity and productivity (e.g. total biomass), a function which can underpin crop production or forage for cattle (Tilman et al. 1994a; Tilman et al. 2014), but studies are now increasingly exploring biodiversity-ecosystem function relationship at large spatial and temporal scales and for multiple functions (Hector \& Bagchi 2007; Maestre et al. 2012; Lefcheck et al. 2015; Oliver et al. 2016; Isbell et al. 2017). These studies have often found positive non-linear relationships, in which ecosystem functions are higher in species mixtures of higher diversity, but where this effect begins to level off and saturate after a certain diversity is reached (Balvanera et al. 2006; O'Connor et al. 2017). There are several suggested mechanisms underlying these relationships, one is the increased likelihood of including a particularly high-performing species in an assemblage as species diversity increases (often termed 'selection' effects; Loreau \& Hector 2001), another is the potential for multiple species in a mixture to perform better through partitioning of resources or facilitation effects ('complementarity'). When considering the delivery of ecosystem functions over time, there is an additional effect that asynchrony in species dynamics, caused through differential responses to environmental changes or through internal competition dynamics, can lead to more stable functioning in higher species diversity mixtures (Loreau \& de Mazancourt 2013). Finally, when considering multiple functions simultaneously, a mixture of species can lead to more functions being delivered above some minimum threshold (the 'jack-of-all-trades' effect; van der Plas et al. 2016). These mechanisms mean that the loss of species from a community can lead to loss of function, although the exact functional traits of the species lost determines the type and extent of the lost function (Díaz et al. 2013). Although a growing research base is improving understanding of these functional traits (Díaz et al. 2013; Evans et al. 2013) we are still a long way from accurately predicting how ecosystem functions and services will change in response to environmental change (Lavorel \& Garnier 2002; Hooper et al. 2012). In the face of such uncertainty a precautionary principle may be advisable. As 
ecologist Aldo Leopold (1987-1948) once stated: "To keep every cog and wheel is the first precaution of intelligent tinkering”. Of course, maintaining all species in all locations in which they occur would have substantial opportunity costs; for example, being able use that land to grow food or produce energy. Therefore, a critical scientific challenge of the $21^{\text {st }}$ century, is to improve our scientific understanding of environmental risk to inform the preservation and management of biodiversity in concert with meeting other human needs (Oliver 2016).

\section{The role of genetic diversity in ecosystem services}

In addition to the loss of species through extinction, the erosion of genetic diversity in species populations that remain can also impact ecosystem services and human well-being. Genetic diversity is a primary cause of phenotypic (physiological, morphological and behavioural) variation between individuals, which in turn affects ecological functions and the contribution to ecosystem services. In response to environmental perturbations, ecological functions may be less resistant when population genetic diversity is lower (Reusch et al. 2005; Hughes et al. 2008; Sgrò et al. 2011; Forsman \& Wennersten 2015). Thus, for example, crops with higher genetic diversity often tend to produce higher or more stable yields due to decreased damage by diseases and herbivores (Smithson \& Lenne 1996; Hughes et al. 2008). Although they are less frequently considered, the mechanisms underpinning these positive effects of genetic diversity are likely to be similar to those at the species level (i.e. selection effects, complementarity, asynchrony, and 'jack-of-all-trades'). Selection effects may operate, whereby populations of higher genetic diversity are more likely to contain genotypes which are particularly dominant for a given function. Furthermore, there may be complementarity effects, whereby diverse populations more effectively exploit a particular resource (Reusch et al. 2005; Hughes et al. 2008; Sgrò et al. 2011; Forsman \& Wennersten 2015). Although untested, 'jack-of-all-trades' effects might also be expected to operate, whereby diverse mixtures of genotypes would carry out more ecological functions above some minimum threshold.

\section{Increased importance of biodiversity over longer time scales}

Both genetic and species diversity are known to be important for ecological functioning under the environmental conditions at any given point in time. However, their importance may become even greater under longer time scales in which environmental perturbations (e.g. extreme weather events) are more likely, and where mean environmental conditions may shift 
(e.g. under chronic drivers such as climate warming or nutrient deposition). In these cases, species, or genotypes of species, that are currently dominant and provide essential ecological functions may fare less well under the new environmental conditions, and other species/genotypes may be needed to step up and deliver functions. For example, under climatic warming and increased extreme events such as drought, specific pollinators species may decline (Ives et al. 1999; Yachi \& Loreau 1999; Loreau et al. 2003; Devictor et al. 2012; Oliver et al. 2015c; Oliver et al. 2017), and only if regional species pools are large enough will they be able to provide species to replace the lost pollination function. Therefore, there is an 'insurance' effect provided by higher genetic and species diversity, and biodiversity increases the resilience of ecosystem functions to environmental change (i.e. a better capacity to resist or recover rapidly from environmental perturbations, thereby maintaining function above a socially acceptable level; Oliver et al. 2015a; Folke 2016). Therefore, the importance of biodiversity is context-dependent, and the longer the time window of interest (containing a wider range of environmental conditions) the more biodiversity is needed to ensure resilience of ecosystem functions and services (Oliver 2016).

\section{Recent responses to mitigate anthropogenic-driven biodiversity loss}

What has been the global policy response to the global biodiversity losses and changes outlined in this article? The Convention of Biological Diversity (CBD) is an international treaty signed by over 160 countries, with the aim of addressing biodiversity loss. In 2002, these countries committed to "to achieve by 2010 a significant reduction of the current rate of biodiversity loss". This target was not achieved - an analysis in 2010 by Butchart et al. found that that biodiversity has continued to decline over the past four decades, with eight out of 10 state indicators showing negative trends. After 2010, CBD targets were revised with a set of 'Aichi' targets set for 2020 (CBD 2010). Again, the aim was to prevent further biodiversity loss, with the target that "By 2020 the extinction of known threatened species has been prevented and their conservation status, particularly of those most in decline, has been improved and sustained" (Aichi Target 12). However, in the face of existing species trends achieving this target by 2020 looks unlikely (Dirzo et al. 2014; Newbold et al. 2015; WWF 2016). The CBD targets also recognise genetic diversity stating that "By 2020, the genetic diversity of cultivated plants and farmed and domesticated animals and of wild relatives, including other socio-economically as well as culturally valuable species, is maintained, and strategies have been developed and implemented for minimizing genetic erosion and safeguarding their genetic diversity". However, there are very few studies which have 
measured trends in genetic diversity in wild species, so it is not possible to assess whether safeguarding genetic diversity has been achieved.

It is easy to criticise these global targets but their lack of achievement is a mark against the whole of human society, not just national governments. Addressing biodiversity loss means tackling the primary drivers of declines. Anthropogenic biodiversity loss is not a new phenomenon; it has been occurring ever since the expansion of early humans across the planet. For example, hunting by humans and habitat change (e.g. land clearing by fire) is likely to have been instrumental in the widespread extinction of megafauna in the Pleistocene, even though factors such as natural climatic change may have had an additional role (Miller et al. 1999; Barnosky et al. 2004; Miller et al. 2005; Dale Guthrie 2006). Since then, a whole new suite of anthropogenic drivers have been added (e.g. nitrogen and phosphorus pollution) and biodiversity declines have accelerated (Steffen et al. 2015a). A meta-analysis of hundreds of experiments and observations by Murphy et al. (Murphy \& Romanuk 2014), concluded that land-use change and species invasions have had the greatest impact in driving local species losses, followed by habitat loss, nutrient addition and increases in temperature. Notably, human-driven climate change is not thought to be a primary cause of past and current extinctions, but that could change dramatically in the future with greater rates of climate warming (Urban 2015), especially when extreme events are factored into projections (Oliver et al. 2015c) and in light of synergistic interactions between climate and land use change and biodiversity (Oliver \& Morecroft 2014; Oliver et al. 2017).

\section{Synthesis and Future challenges}

To prevent damaging consequences of accelerated biodiversity loss caused by human activities we need to better understand and monitor changes in biodiversity. This includes understanding the drivers of biodiversity change (including processes of biodiversity generation as well as loss), as well as the interactions between species and genetic diversity. A recent focus on ecosystem services in environmental management literature and policy has driven rapid development of socioeconomic research into natural capital and biodiversity accounting. Under this new paradigm, biodiversity is increasingly referred to as a 'natural capital stock' underpinning the flow of ecosystem services. However, there is a danger that this ignores the highly dynamic and complex nature of biodiversity. First, biodiversity is composed of both genetic and species diversity, although the former is nearly always ignored in ecosystem accounting. Second, interactions between the stocks of genetic and species diversity are common, as well as internal feedback mechanisms, and so biodiversity levels 
may not be at equilibrium. For example, extinction debts are known in many ecological systems whereby biodiversity loss continues long (sometimes decades) after initial drivers of change are removed (Tilman et al. 1994b; Kuussaari et al. 2009; Gonzalez 2013). Third, human activities drive biodiversity generation processes, not exclusively biodiversity extinctions.

Researchers differ in how they see this balance of generation and erosion playing out in the future. Some see an emerging period of novel biodiversity generation, through rapid reassortment of species around the globe, hybridisation between alien and native species, and novel ecosystems driving new evolutionary change, along with new technologies such as genetic modification; all leading to rapid speciation rates. On the contrary, other researchers predict further catastrophic extinctions in genetic diversity, population abundance and species diversity, which will dwarf the processes generating biodiversity. Many fear this will lead to loss of ecosystem services and will have severe impacts on humans, as well as the ethical implications of biodiversity destruction. However, what all these researchers do seem to have consensus upon is the primary role of humans in driving extensive changes to genetic and species diversity and the re-assortment of species composition on a planetary scale. It is now abundantly clear that biodiversity generation and speciation have been irreversibly altered under human activities on a scale which justifies the naming of the Anthropocene era. To understand the impacts of these substantial interventions and to manage their impacts wisely we need to address critical gaps in our knowledge. We need to better understand drivers of biodiversity change and how these vary across regions and over time, and we need better ways to monitor biodiversity change. This biodiversity monitoring needs to be at both the species and genetic level, across different global environments and across different scales (i.e. $\alpha \beta$ and $\gamma$ diversity change). It must not be restricted to just a subset of charismatic groups which may not be representative of importance functional units. Harnessing new technologies, such as remote sensing and metagenomics, as well as participatory (e.g. citizen science) monitoring schemes will be necessary to address this challenge (Ji et al. 2013; Kuenzer et al. 2014; Thomsen \& Willerslev 2015). Finally, we also need to better understand the interactions between species and genetic diversity in order to develop a more comprehensive understanding of dynamic biodiversity stocks. Only by developing such knowledge can we manage ecosystems in such a way that the ecosystem services that underpin human well-being are safeguarded and in which the intrinsic value of the Earth's biodiversity is preserved for future generations. 


\section{References}

Abbott, R., Albach, D., Ansell, S., Arntzen, J.W., Baird, S.J.E., Bierne, N., Boughman, J., Brelsford, A., Buerkle, C.A., Buggs, R., Butlin, R.K., Dieckmann, U., Eroukhmanoff, F., Grill, A., Cahan, S.H., Hermansen, J.S., Hewitt, G., Hudson, A.G., Jiggins, C., Jones, J., Keller, B., Marczewski, T., Mallet, J., Martinez-Rodriguez, P., Möst, M., Mullen, S., Nichols, R., Nolte, A.W., Parisod, C., Pfennig, K., Rice, A.M., Ritchie, M.G., Seifert, B., Smadja, C.M., Stelkens, R., Szymura, J.M., Väinölä, R., Wolf, J.B.W. \& Zinner, D. (2013). Hybridization and speciation. Journal of Evolutionary Biology, 26, 229-246.

Allendorf, F.W., England, P.R., Luikart, G., Ritchie, P.A. \& Ryman, N. (2008). Genetic effects of harvest on wild animal populations. Trends Ecol. Evol., 23, 327-337.

Allentoft, M. \& O’Brien, J. (2010a). Global Amphibian Declines, Loss of Genetic Diversity and Fitness: A Review. Diversity, 2, 47.

Allentoft, M.E. \& O’Brien, J. (2010b). Global amphibian declines, loss of genetic diversity and fitness: a review. Diversity, 2, 47-71.

Alroy, J. (1996). Constant extinction, constrained diversification, and uncoordinated stasis in North American mammals. Palaeogeography, Palaeoclimatology, Palaeoecology, $127,285-311$.

Anthony, K.R.N., Kline, D.I., Diaz-Pulido, G., Dove, S. \& Hoegh-Guldberg, O. (2008). Ocean acidification causes bleaching and productivity loss in coral reef builders. PNAS, 105, 17442-17446.

Austerlitz, F., Mariette, S., Machon, N., Gouyon, P.-H. \& Godelle, B. (2000). Effects of colonization processes on genetic diversity: differences between annual plants and tree species. Genetics, 154, 1309-1321.

Balvanera, P., Pfisterer, A.B., Buchman, N., Jing-Shen, H., Nakashizuka, T., Raffaelli, D. \& Schmid, B. (2006). Quantifying the evidence for biodiversity effects on ecosystem functioning and services. Ecol. Lett., 9, 1146-1156.

Barnosky, A.D., Hadly, E.A., Bascompte, J., Berlow, E.L., Brown, J.H., Fortelius, M., Getz, W.M., Harte, J., Hastings, A., Marquet, P.A., Martinez, N.D., Mooers, A., Roopnarine, P., Vermeij, G., Williams, J.W., Gillespie, R., Kitzes, J., Marshall, C., Matzke, N., Mindell, D.P., Revilla, E. \& Smith, A.B. (2012). Approaching a state shift in Earth's biosphere. Nature, 486, 52-58. 
Barnosky, A.D., Koch, P.L., Feranec, R.S., Wing, S.L. \& Shabel, A.B. (2004). Assessing the Causes of Late Pleistocene Extinctions on the Continents. Science, 306, 70-75.

Barnosky, A.D., Matzke, N., Tomiya, S., Wogan, G.O.U., Swartz, B., Quental, T.B., Marshall, C., McGuire, J.L., Lindsey, E.L., Maguire, K.C., Mersey, B. \& Ferrer, E.A. (2011). Has the Earth's sixth mass extinction already arrived? Nature, 471, 51-57.

Barrick, J.E. \& Lenski, R.E. (2013). Genome dynamics during experimental evolution. Nat Rev Genet, 14, 827-839.

Benton, M. (1995). Diversification and extinction in the history of life. Science, 268, 52-58.

Bonnin, I., Bonneuil, C., Goffaux, R., Montalent, P. \& Goldringer, I. (2014). Explaining the decrease in the genetic diversity of wheat in France over the 20th century. Agriculture, Ecosystems \& Environment, 195, 183-192.

Braat, L.C. (2016). Ecosystem Services. Oxford Research Encyclopedia of Environmental Science.

Brand, F. (2009). Critical natural capital revisited: Ecological resilience and sustainable development. Ecol. Econ., 68, 605-612.

Brown, J.H. \& Kodric-Brown, A. (1977). Turnover Rates in Insular Biogeography: Effect of Immigration on Extinction. Ecology, 58, 445-449.

Brown, J.H. \& Lomolino, M.V. (2000). Concluding remarks: historical perspective and the future of island biogeography theory. Glob. Ecol. Biogeogr., 9, 87-92.

Bull, J.W. \& Maron, M. (2016). How humans drive speciation as well as extinction. Proc. Roy. Soc. B, 283, 20160600.

Bulmer, M.G. (1971). The effect of selection on genetic variability. The American Naturalist, $105,201-211$.

Burt, A. (2000). Perspective: sex, recombination, and the efficacy of selection-was Weismann right? Evolution, 54, 337-351.

Butchart, S.H.M., Walpole, M., Collen, B., van Strien, A., Scharlemann, J.P.W., Almond, R.E.A., Baillie, J.E.M., Bomhard, B., Brown, C., Bruno, J., Carpenter, K.E., Carr, G.M., Chanson, J., Chenery, A.M., Csirke, J., Davidson, N.C., Dentener, F., Foster, M., Galli, A., Galloway, J.N., Genovesi, P., Gregory, R.D., Hockings, M., Kapos, V., Lamarque, J.-F., Leverington, F., Loh, J., McGeoch, M.A., McRae, L., Minasyan, A., Morcillo, M.H., Oldfield, T.E.E., Pauly, D., Quader, S., Revenga, C., Sauer, J.R., Skolnik, B., Spear, D., Stanwell-Smith, D., Stuart, S.N., Symes, A., Tierney, M., Tyrrell, T.D., Vie, J.-C. \& Watson, R. (2010). Global biodiversity: indicators of recent declines. Science, 328, 1164-1168. 
Byrne, K. \& Nichols, R.A. (1999). Culex pipiens in London Underground tunnels: differentiation between surface and subterranean populations. Heredity, 82, 7-15.

Cadotte, M.W., Carscadden, K. \& Mirotchnick, N. (2011). Beyond species: functional diversity and the maintenance of ecological processes and services. J. Appl. Ecol., 48, 1079-1087.

Cardinale, B.J., Duffy, J.E., Gonzalez, A., Hooper, D.U., Perrings, C., Venail, P., Narwani, A., Mace, G.M., Tilman, D., Wardle, D.A., Kinzig, A.P., Daily, G.C., Loreau, M., Grace, J.B., Larigauderie, A., Srivastava, D.S. \& Naeem, S. (2012). Biodiversity loss and its impact on humanity. Nature, 486, 59-67.

CBD (1992). Convention on Biological Diversity Article 2. Use of Terms. https://www.cbd.int/convention/articles/default.shtml?a=cbd-02 accessed 05.06.17. CBD (2010). COP 10 Decision X/2. Strategic Plan for Biodiversity 2011-2020. http://www.cbd.int/ accessed 10.03.14.

Ceballos, G., Ehrlich, P.R., Barnosky, A.D., García, A., Pringle, R.M. \& Palmer, T.M. (2015). Accelerated modern human-induced species losses: Entering the sixth mass extinction. Science Advances, 1.

Chao, A., Chiu, C.-H. \& Jost, L. (2010). Phylogenetic diversity measures based on Hill numbers. Philosophical Transactions of the Royal Society B: Biological Sciences, 365, 3599-3609.

Christian, J. (2014). Accounting for Biodiversity. Routledge, London, UK.

Church, A. \& et al. (2011). Chapter 16: Cultural Services. In: The UK National Ecosystem Asssessment Technical Report. http://uknea.unepwcmc.org/LinkClick.aspx?fileticket $=$ m\%2BvhAV3c9uk\%3D\&tabid=82 UK National Ecosystem Assessment, UNEP-WCMC, Cambridge, UK Cambridge, UK.

Clark, N.E., Lovell, R., Wheeler, B.W., Higgins, S.L., Depledge, M.H. \& Norris, K. (2014). Biodiversity, cultural pathways, and human health: a framework. Trends Ecol. Evol., 29, 198-204.

Crow, J.F. (1994). Advantages of sexual reproduction. Developmental Genetics, 15, 205-213.

Dale Guthrie, R. (2006). New carbon dates link climatic change with human colonization and Pleistocene extinctions. Nature, 441, 207-209.

Devictor, V., van Swaay, C., Brereton, T., Brotons, L., Chamberlain, D., Heliola, J., Herrando, S., Julliard, R., Kuussaari, M., Lindstrom, A., Reif, J., Roy, D.B., Schweiger, O., Settele, J., Stefanescu, C., Van Strien, A., Van Turnhout, C., Vermouzek, Z., WallisDeVries, M., Wynhoff, I. \& Jiguet, F. (2012). Differences in 
the climatic debts of birds and butterflies at a continental scale. Nature Clim. Change, $2,121-124$.

Díaz, S., Purvis, A., Cornelissen, J.H.C., Mace, G.M., Donoghue, M.J., Ewers, R.M., Jordano, P. \& Pearse, W.D. (2013). Functional traits, the phylogeny of function, and ecosystem service vulnerability. Ecol. and Evol., 3, 2958-2975.

Dirzo, R., Young, H.S., Galetti, M., Ceballos, G., Isaac, N.J. \& Collen, B. (2014). Defaunation in the Anthropocene. Science, 345, 401-406.

Dornelas, M., Gotelli, N.J., McGill, B., Shimadzu, H., Moyes, F., Sievers, C. \& Magurran, A.E. (2014). Assemblage Time Series Reveal Biodiversity Change but Not Systematic Loss. Science, 344, 296-299.

Drake, J.W., Charlesworth, B., Charlesworth, D. \& Crow, J.F. (1998). Rates of Spontaneous Mutation. Genetics, 148, 1667-1686.

EEA (2015). Livestock genetic diversity. European Environment Agency Indicators. ProdID: IND-146-en / SEBI 006 https://www.eea.europa.eu/data-andmaps/indicators/livestock-genetic-diversity/livestock-genetic-diversity-assessmentpublished accessed 12.06.17

Erwin, D.H. (2012). Novelties that change carrying capacity. Journal of Experimental Zoology Part B: Molecular and Developmental Evolution, 318, 460-465.

Evans, M.R., Bithell, M., Cornell, S.J., Dall, S.R.X., Díaz, S., Emmott, S., Ernande, B., Grimm, V., Hodgson, D.J., Lewis, S.L., Mace, G.M., Morecroft, M., Moustakas, A., Murphy, E., Newbold, T., Norris, K.J., Petchey, O., Smith, M., Travis, J.M.J. \& Benton, T.G. (2013). Predictive systems ecology. Proc. Roy. Soc. B, 280.

Ezard, T.H.G. \& Purvis, A. (2016). Environmental changes define ecological limits to species richness and reveal the mode of macroevolutionary competition. Ecol. Lett., 19, 899906.

Feindt, W., Fincke, O. \& Hadrys, H. (2014). Still a one species genus? Strong genetic diversification in the world's largest living odonate, the Neotropical damselfly Megaloprepus caerulatus. Conservation Genetics, 15, 469-481.

Fitzpatrick, B.M., Fordyce, J.A. \& Gavrilets, S. (2009). Pattern, process and geographic modes of speciation. Journal of Evolutionary Biology, 22, 2342-2347.

Folke, C. (2016). Resilience. Oxford Research Encyclopedia of Environmental Science.

Forsman, A. \& Wennersten, L. (2015). Inter-individual variation promotes ecological success of populations and species: evidence from experimental and comparative studies. Ecography, online early. 
Garner, A., Rachlow, J.L. \& Hicks, J.F. (2005). Patterns of Genetic Diversity and Its Loss in Mammalian Populations. Cons. Biol., 19, 1215-1221.

Gascon, C., Brooks, Thomas M., Contreras-MacBeath, T., Heard, N., Konstant, W., Lamoreux, J., Launay, F., Maunder, M., Mittermeier, Russell A., Molur, S., Al Mubarak, Razan K., Parr, Michael J., Rhodin, Anders G.J., Rylands, Anthony B., Soorae, P., Sanderson, James G. \& Vié, J.-C. (2015). The Importance and Benefits of Species. Current Biology, 25, R431-R438.

Gilbert, F.S. (1980). The equilibrium theory of island biogeography: fact or fiction? Journal of Biogeography, 7, 209-235.

Gladieux, P., GuÉRin, F., Giraud, T., Caffier, V., Lemaire, C., Parisi, L., Didelot, F. \& Le Cam, B. (2011). Emergence of novel fungal pathogens by ecological speciation: importance of the reduced viability of immigrants. Molecular Ecology, 20, 45214532.

Gonzalez, A. (2013). The ecological deficit. Nature, 503, 206.

Gonzalez, A., Cardinale, B.J., Allington, G.R.H., Byrnes, J., Arthur Endsley, K., Brown, D.G., Hooper, D.U., Isbell, F., O'Connor, M.I. \& Loreau, M. (2016). Estimating local biodiversity change: a critique of papers claiming no net loss of local diversity. Ecology, 97, 1949-1960.

Gorelick, R. \& Heng, H.H.Q. (2011). Sex reduces genetic variation: a multidisciplinary review. Evolution, 65, 1088-1098.

Gross, B.L., Henk, A.D., Richards, C.M., Fazio, G. \& Volk, G.M. (2014). Genetic diversity in Malus $\times$ domestica (Rosaceae) through time in response to domestication. American Journal of Botany, 101, 1770-1779.

Hamilton, W.D., Axelrod, R. \& Tanese, R. (1990). Sexual reproduction as an adaptation to resist parasites (a review). PNAS, 87, 3566-3573.

Harmon, L.J. \& Harrison, S. (2015). Species diversity is dynamic and unbounded at local and continental scales. The American Naturalist, 185, 584-593.

Harnik, P.G., Lotze, H.K., Anderson, S.C., Finkel, Z.V., Finnegan, S., Lindberg, D.R., Liow, L.H., Lockwood, R., McClain, C.R. \& McGuire, J.L. (2012). Extinctions in ancient and modern seas. Trends Ecol. Evol., 27, 608-617.

Hauser, L., Adcock, G.J., Smith, P.J., Bernal Ramírez, J.H. \& Carvalho, G.R. (2002). Loss of microsatellite diversity and low effective population size in an overexploited population of New Zealand snapper (Pagrus auratus). PNAS, 99, 11742-11747. 
Hector, A. \& Bagchi, R. (2007). Biodiversity and ecosystem multifunctionality. Nature, 448, 188-190.

Helfenstein, J. \& Kienast, F. (2014). Ecosystem service state and trends at the regional to national level: A rapid assessment. Ecol. Ind., 36, 11-18.

Hendry, A.P., Farrugia, T.J. \& Kinnison, M.T. (2008). Human influences on rates of phenotypic change in wild animal populations. Molecular Ecology, 17, 20-29.

Hersch-Green, E.I., Turley, N.E. \& Johnson, M.T.J. (2011). Community genetics: what have we accomplished and where should we be going? Philosophical Transactions of the Royal Society B: Biological Sciences, 366, 1453-1460.

Hooper, D.U., Adair, E.C., Cardinale, B.J., Byrnes, J.E.K., Hungate, B.A., Matulich, K.L., Gonzalez, A., Duffy, J.E., Gamfeldt, L. \& O’Connor, M.I. (2012). A global synthesis reveals biodiversity loss as a major driver of ecosystem change. Nature, 486, 105.

Hughes, A.R., Inouye, B.D., Johnson, M.T., Underwood, N. \& Vellend, M. (2008). Ecological consequences of genetic diversity. Ecol. Lett., 11, 609-623.

Hughes, J.B., Daily, G.C. \& Ehrlich, P.R. (1997). Population Diversity: Its Extent and Extinction. Science, 278, 689-692.

Hutchinson, W.F., Oosterhout, C.v., Rogers, S.I. \& Carvalho, G.R. (2003). Temporal analysis of archived samples indicates marked genetic changes in declining North Sea cod (Gadus morhua). Proc. Roy. Soc. B, 270, 2125-2132.

Hyten, D.L., Song, Q., Zhu, Y., Choi, I.-Y., Nelson, R.L., Costa, J.M., Specht, J.E., Shoemaker, R.C. \& Cregan, P.B. (2006). Impacts of genetic bottlenecks on soybean genome diversity. PNAS, 103, 16666-16671.

Isbell, F., Gonzalez, A., Loreau, M., Cowles, J., Diaz, S., Hector, A., Mace, G.M., Wardle, D.A., O'Connor, M.I., Duffy, J.E., Turnbull, L.A., Thompson, P.L. \& Larigauderie, A. (2017). Linking the influence and dependence of people on biodiversity across scales. Nature, 546, 65-72.

Isbell, F., Reich, P.B., Tilman, D., Hobbie, S.E., Polasky, S. \& Binder, S. (2013). Nutrient enrichment, biodiversity loss, and consequent declines in ecosystem productivity. PNAS, 110, 11911-11916.

IUCN (2017). The IUCN Red List of Threatened Species Version 2017-1 http://www.iucnredlist.org/ accessed 15.6.17.

Ives, A.R., Gross, K. \& Klug, J.L. (1999). Stability and Variability in Competitive Communities. Science, 286, 542-544. 
Ji, Y., Ashton, L., Pedley, S.M., Edwards, D.P., Tang, Y., Nakamura, A., Kitching, R., Dolman, P.M., Woodcock, P., Edwards, F.A., Larsen, T.H., Hsu, W.W., Benedick, S., Hamer, K.C., Wilcove, D.S., Bruce, C., Wang, X., Levi, T., Lott, M., Emerson, B.C. \& Yu, D.W. (2013). Reliable, verifiable and efficient monitoring of biodiversity via metabarcoding. Ecol. Lett., 16, 1245-1257.

Jones, M.J. (2010). Accounting for the environment: Towards a theoretical perspective for environmental accounting and reporting. Accounting Forum, 34, 123-138.

Kareiva, P., Tallis, H., Ricketts, T.H., Daily, G.C. \& Polasky, S. (2011). Natural Capital: Theory and Practice of Mapping Ecosystem Services. Oxford University Press, Oxford.

Kauffman, E.G. \& Harries, P.J. (1996). The importance of crisis progenitors in recovery from mass extinction. Geological Society, London, Special Publications, 102, 15-39.

Kawecki, T.J. \& Ebert, D. (2004). Conceptual issues in local adaptation. Ecol. Lett., 7, 1225 1241.

Kleijn, D., Winfree, R., Bartomeus, I., Carvalheiro, L.G., Henry, M., Isaacs, R., Klein, A.-M., Kremen, C., M'Gonigle, L.K., Rader, R., Ricketts, T.H., Williams, N.M., Lee Adamson, N., Ascher, J.S., Báldi, A., Batáry, P., Benjamin, F., Biesmeijer, J.C., Blitzer, E.J., Bommarco, R., Brand, M.R., Bretagnolle, V., Button, L., Cariveau, D.P., Chifflet, R., Colville, J.F., Danforth, B.N., Elle, E., Garratt, M.P.D., Herzog, F., Holzschuh, A., Howlett, B.G., Jauker, F., Jha, S., Knop, E., Krewenka, K.M., Le Féon, V., Mandelik, Y., May, E.A., Park, M.G., Pisanty, G., Reemer, M., Riedinger, V., Rollin, O., Rundlöf, M., Sardiñas, H.S., Scheper, J., Sciligo, A.R., Smith, H.G., Steffan-Dewenter, I., Thorp, R., Tscharntke, T., Verhulst, J., Viana, B.F., Vaissière, B.E., Veldtman, R., Ward, K.L., Westphal, C. \& Potts, S.G. (2015). Delivery of crop pollination services is an insufficient argument for wild pollinator conservation. Nature Communications, 6, 7414.

Kuenzer, C., Ottinger, M., Wegmann, M., Guo, H., Wang, C., Zhang, J., Dech, S. \& Wikelski, M. (2014). Earth observation satellite sensors for biodiversity monitoring: potentials and bottlenecks. International Journal of Remote Sensing, 35, 6599-6647.

Kuussaari, M., Bommarco, R., Heikkinen, R.K., Helm, A., Krauss, J., Lindborg, R., Öckinger, E., Pärtel, M., Pino, J., Rodà, F., Stefanescu, C., Teder, T., Zobel, M. \& Steffan-Dewenter, I. (2009). Extinction debt: a challenge for biodiversity conservation. Trends Ecol. Evol., 24, 564-571. 
Lavorel, S. \& Garnier, E. (2002). Predicting changes in community composition and ecosystem functioning from plant traits: revisiting the Holy Grail. Functional Ecology, 16, 545-556.

Lefcheck, J.S., Byrnes, J.E.K., Isbell, F., Gamfeldt, L., Griffin, J.N., Eisenhauer, N., Hensel, M.J.S., Hector, A., Cardinale, B.J. \& Duffy, J.E. (2015). Biodiversity enhances ecosystem multifunctionality across trophic levels and habitats. Nat Commun, 6.

Lenormand, T. (2002). Gene flow and the limits to natural selection. Trends Ecol. Evol., 17, 183-189.

Loreau, M. \& de Mazancourt, C. (2013). Biodiversity and ecosystem stability: a synthesis of underlying mechanisms. Ecol. Lett., 16, 106-115.

Loreau, M. \& Hector, A. (2001). Partitioning selection and complementarity in biodiversity experiments. Nature, $412,72-76$.

Loreau, M., Mouquet, N. \& Gonzalez, A. (2003). Biodiversity as spatial insurance in heterogeneous landscapes. PNAS, 100, 12765-12770.

MacArthur, R.H. \& Wilson, E.O. (1967). The Theory of Island Biogeography. Princeton University Press, Princeton, NJ.

Mace, G.M., Norris, K. \& Fitter, A.H. (2012). Biodiversity and ecosystem services: a multilayered relationship. Trends Ecol. Evol., 27, 19-26.

Maebe, K., Meeus, I., Vray, S., Claeys, T., Dekoninck, W., Boevé, J.-L., Rasmont, P. \& Smagghe, G. (2016). A century of temporal stability of genetic diversity in wild bumblebees. 6,38289 .

Maestre, F.T., Quero, J.L., Gotelli, N.J., Escudero, A., Ochoa, V., Delgado-Baquerizo, M., García-Gómez, M., Bowker, M.A., Soliveres, S., Escolar, C., García-Palacios, P., Berdugo, M., Valencia, E., Gozalo, B., Gallardo, A., Aguilera, L., Arredondo, T., Blones, J., Boeken, B., Bran, D., Conceição, A.A., Cabrera, O., Chaieb, M., Derak, M., Eldridge, D.J., Espinosa, C.I., Florentino, A., Gaitán, J., Gatica, M.G., Ghiloufi, W., Gómez-González, S., Gutiérrez, J.R., Hernández, R.M., Huang, X., HuberSannwald, E., Jankju, M., Miriti, M., Monerris, J., Mau, R.L., Morici, E., Naseri, K., Ospina, A., Polo, V., Prina, A., Pucheta, E., Ramírez-Collantes, D.A., Romão, R., Tighe, M., Torres-Díaz, C., Val, J., Veiga, J.P., Wang, D. \& Zaady, E. (2012). Plant Species Richness and Ecosystem Multifunctionality in Global Drylands. Science, 335, 214-218.

Magurran, A.E. (1988). Ecological diversity and its measurement. Chapman and Hall, London. 
Magurran, A.E. (2004). Measuring biological diversity. Blackwell Science., Oxford, UK. Mallet, J. (2007). Hybrid speciation. Nature, 446, 279.

Marshall, C.R. \& Quental, T.B. (2016). The uncertain role of diversity dependence in species diversification and the need to incorporate time-varying carrying capacities. Philosophical Transactions of the Royal Society B: Biological Sciences, 371.

Mascaro, J., Hughes, R.F. \& Schnitzer, S.A. (2012). Novel forests maintain ecosystem processes after the decline of native tree species. Ecological Monographs, 82, 221228.

McGhee, G.R., Sheehan, P.M., Bottjer, D.J. \& Droser, M.L. (2004). Ecological ranking of Phanerozoic biodiversity crises: ecological and taxonomic severities are decoupled. Palaeogeography, Palaeoclimatology, Palaeoecology, 211, 289-297.

McKinney, M.L. (1997). Extinction vulnerability and selectivity: Combining Ecological and Paleontological Views. Ann. Rev. Ecol. Syst., 28, 495-516.

Miller, G.H., Fogel, M.L., Magee, J.W., Gagan, M.K., Clarke, S.J. \& Johnson, B.J. (2005). Ecosystem Collapse in Pleistocene Australia and a Human Role in Megafaunal Extinction. Science, 309, 287-290.

Miller, G.H., Magee, J.W., Johnson, B.J., Fogel, M.L., Spooner, N.A., McCulloch, M.T. \& Ayliffe, L.K. (1999). Pleistocene Extinction of Genyornis newtoni Human Impact on Australian Megafauna. Science, 283, 205-208.

Miraldo, A., Li, S., Borregaard, M.K., Flórez-Rodríguez, A., Gopalakrishnan, S., Rizvanovic, M., Wang, Z., Rahbek, C., Marske, K.A. \& Nogués-Bravo, D. (2016). An Anthropocene map of genetic diversity. Science, 353, 1532-1535.

Mittelbach, G.G., Schemske, D.W., Cornell, H.V., Allen, A.P., Brown, J.M., Bush, M.B., Harrison, S.P., Hurlbert, A.H., Knowlton, N., Lessios, H.A., McCain, C.M., McCune, A.R., McDade, L.A., McPeek, M.A., Near, T.J., Price, T.D., Ricklefs, R.E., Roy, K., Sax, D.F., Schluter, D., Sobel, J.M. \& Turelli, M. (2007). Evolution and the latitudinal diversity gradient: speciation, extinction and biogeography. Ecol. Lett., 10, 315-331.

Monfreda, C., Wackernagel, M. \& Deumling, D. (2004). Establishing national natural capital accounts based on detailed Ecological Footprint and biological capacity assessments. Land Use Policy, 21, 231-246.

Mouillot, D., Bellwood, D.R., Baraloto, C., Chave, J., Galzin, R., Harmelin-Vivien, M., Kulbicki, M., Lavergne, S., Lavorel, S., Mouquet, N., Paine, C.E.T., Renaud, J. \& Thuiller, W. (2013). Rare Species Support Vulnerable Functions in High-Diversity Ecosystems. PLOS Biology, 11, e1001569. 
Moya-Laraño, J. (2011). Genetic variation, predator-prey interactions and food web structure. Philosophical Transactions of the Royal Society B: Biological Sciences, $366,1425-1437$.

Muller, H.J. (1932). Some Genetic Aspects of Sex. The American Naturalist, 66, 118-138. Murphy, G.E.P. \& Romanuk, T.N. (2014). A meta-analysis of declines in local species richness from human disturbances. Ecol. and Evol., 4, 91-103.

Myers, N., Mittermeier, R.A., Mittermeier, C.G., da Fonseca, G.A.B. \& Kent, J. (2000). Biodiversity hotspots for conservation priorities. Nature, 403, 853-858.

Newbold, T., Hudson, L.N., Arnell, A.P., Contu, S., De Palma, A., Ferrier, S., Hill, S.L.L., Hoskins, A.J., Lysenko, I., Phillips, H.R.P., Burton, V.J., Chng, C.W.T., Emerson, S., Gao, D., Pask-Hale, G., Hutton, J., Jung, M., Sanchez-Ortiz, K., Simmons, B.I., Whitmee, S., Zhang, H., Scharlemann, J.P.W. \& Purvis, A. (2016). Has land use pushed terrestrial biodiversity beyond the planetary boundary? A global assessment. Science, 353, 288-291.

Newbold, T., Hudson, L.N., Hill, S.L.L., Contu, S., Lysenko, I., Senior, R.A., Borger, L., Bennett, D.J., Choimes, A., Collen, B., Day, J., De Palma, A., Diaz, S., EcheverriaLondono, S., Edgar, M.J., Feldman, A., Garon, M., Harrison, M.L.K., Alhusseini, T., Ingram, D.J., Itescu, Y., Kattge, J., Kemp, V., Kirkpatrick, L., Kleyer, M., Correia, D.L.P., Martin, C.D., Meiri, S., Novosolov, M., Pan, Y., Phillips, H.R.P., Purves, D.W., Robinson, A., Simpson, J., Tuck, S.L., Weiher, E., White, H.J., Ewers, R.M., Mace, G.M., Scharlemann, J.P.W. \& Purvis, A. (2015). Global effects of land use on local terrestrial biodiversity. Nature, 520, 45-50.

O'Connor, M.I., Gonzalez, A., Byrnes, J.E.K., Cardinale, B.J., Duffy, J.E., Gamfeldt, L., Griffin, J.N., Hooper, D., Hungate, B.A., Paquette, A., Thompson, P.L., Dee, L.E. \& Dolan, K.L. (2017). A general biodiversity-function relationship is mediated by trophic level. Oikos, 126, 18-31.

Oliver, T.H. (2016). How much biodiversity loss is too much? Science, 353, 220-221.

Oliver, T.H., Gillings, S., Pearce-Higgins, J.W., Brereton, T., Crick, H.P.Q., Duffield, S.J., Morecroft, M.D. \& Roy, D.B. (2017). Large extents of intensive land use limit community reorganisation during climate warming. Glob. Ch. Biol., 23, 2272-2283.

Oliver, T.H., Heard, M.S., Isaac, N.J.B., Roy, D.B., Procter, D.A., Eigenbrod, F., Freckleton, R.P., Hector, A., Orme, C.D.L., Petchey, O.L., Proenca, V., Raffaelli, D., Suttle, K.B., Mace, G.M., Martin-Lopez, B., Woodcock, B.A. \& Bullock, J.M. (2015a). 
Biodiversity and the resilience of ecosystem services. Trends Ecol. Evol., 30, 673684.

Oliver, T.H., Heard, M.S., Isaac, N.J.B., Roy, D.B., Procter, D.A., Eigenbrod, F., Freckleton, R.P., Hector, A., Orme, C.D.L., Petchey, O.L., Proenca, V., Raffaelli, D., Suttle, K.B., Mace, G.M., Martin-Lopez, B., Woodcock, B.A. \& Bullock, J.M. (2016). A synthesis is emerging between biodiversity-ecosystem function and ecological resilience research - Reply to Mori. Trends Ecol. Evol., 31, 89-92.

Oliver, T.H., Isaac, N.J.B., August, T.A., Woodcock, B.A., Roy, D.B. \& Bullock, J.M. (2015b). Declining resilience of ecosystem functions under biodiversity loss. Nature Communications, 6 .

Oliver, T.H., Marshall, H.H., Morecroft, M.D., Brereton, T.M., Prudhomme, C. \& Huntingford, C. (2015c). Interacting effects of climate change and habitat fragmentation on drought-sensitive butterflies. Nat. Clim. Chng., 5, 941-945.

Oliver, T.H. \& Morecroft, M.D. (2014). Interactions between climate change and land use change on biodiversity: attribution problems, risks, and opportunities. WIRES: Clim. Change, 5, 317-335.

Palkovacs, E.P., Kinnison, M.T., Correa, C., Dalton, C.M. \& Hendry, A.P. (2012). Fates beyond traits: ecological consequences of human-induced trait change. Evol. Appl., 5, 183-191.

Palumbi, S.R. (2001). Humans as the World's Greatest Evolutionary Force. Science, 293, 1786-1790.

Payne, J.L., Bush, A.M., Heim, N.A., Knope, M.L. \& McCauley, D.J. (2016). Ecological selectivity of the emerging mass extinction in the oceans. Science, 353, 1284-1286.

Pereira, H.M., Leadley, P.W. \& AL., E. (2010). Scenarios for global biodiversity in the 21st Century. Science Express.

Petchey, O.L., Hector, A. \& Gaston, K.J. (2004). How do different measures of functional diversity perform? Ecology, 85, 847-857.

Pichler, F.B. \& Baker, C.S. (2000). Loss of genetic diversity in the endemic Hector's dolphin due to fisheries-related mortality. Proc. Roy. Soc. B, 267, 97-102.

Pielou, E.C. (1975). Ecological diversity. John Wiley and Sons., New York.

Pimm, S.L., Jenkins, C.N., Abell, R., Brooks, T.M., Gittleman, J.L., Joppa, L.N., Raven, P.H., Roberts, C.M. \& Sexton, J.O. (2014). The biodiversity of species and their rates of extinction, distribution, and protection. Science, 344, 1246752. 
Pinsky, M.L. \& Palumbi, S.R. (2014). Meta-analysis reveals lower genetic diversity in overfished populations. Molecular Ecology, 23, 29-39.

Pray, L. (2008). DNA Replication and Causes of Mutation. Nature Education 1, 214.

Rabosky, D.L. \& Hurlbert, A.H. (2015). Species richness at continental scales is dominated by ecological limits. The American Naturalist, 185, 572-583.

Rao, C.R. (1982). Diversity and dissimilarity coefficients: a unified approach. Theoretical population biology, 21, 24-43.

Raup, D.M. \& Sepkoski, J.J. (1982). Mass extinctions in the marine fossil record. Science, $215,1501-1503$.

Remme, R.P., Hein, L. \& van Swaay, C.A.M. (2016). Exploring spatial indicators for biodiversity accounting. Ecol. Ind., 70, 232-248.

Reusch, T.B.H., Ehlers, A., Hämmerli, A. \& Worm, B. (2005). Ecosystem recovery after climatic extremes enhanced by genotypic diversity. PNAS, 102, 2826-2831.

Rosenzweig, M.L. (2001). Loss of speciation rate will impoverish future diversity. PNAS, 98, 5404-5410.

Sakamoto, M., Benton, M.J. \& Venditti, C. (2016). Dinosaurs in decline tens of millions of years before their final extinction. PNAS, 113, 5036-5040.

Sala, O.E., Chapin , F.S., Armesto, J.J., Berlow, E., Bloomfield, J., Dirzo, R., HuberSanwald, E., Huenneke, L.F., Jackson, R.B., Kinzig, A., Leemans, R., Lodge, D.M., Mooney, H.A., Oesterheld, M.n., Poff, N.L., Sykes, M.T., Walker, B.H., Walker, M. \& Wall, D.H. (2000). Global Biodiversity Scenarios for the Year 2100. Science, 287, $1770-1774$.

Sax, D.F. \& Gaines, S.D. Species diversity: from global decreases to local increases. Trends Ecol. Evol., 18, 561-566.

Schluter, D. \& Conte, G.L. (2009). Genetics and ecological speciation. PNAS, 106, 99559962.

Schluter, D. \& Pennell, M.W. (2017). Speciation gradients and the distribution of biodiversity. Nature, 546, 48-55.

Sgrò, C.M., Lowe, A.J. \& Hoffmann, A.A. (2011). Building evolutionary resilience for conserving biodiversity under climate change. Evol. Appl., 4, 326-337.

Sherkow, J.S. \& Greely, H.T. (2013). What if extinction is not forever? Science, 340, 32-33.

Slarkin, M. (1985). Gene flow in natural populations. Ann. Rev. Ecol. Syst., 16, 393-430.

Smith, P.J., Francis, R.I.C.C. \& McVeagh, M. (1991). Loss of genetic diversity due to fishing pressure. Fisheries Research, 10, 309-316. 
Smithson, J.B. \& Lenne, J.M. (1996). Varietal mixtures: a viable strategy for sustainable productivity in subsistence agriculture. Annals of Applied Biology, 128, 127-158.

Solé, R.V., Montoya, J.M. \& Erwin, D.H. (2002). Recovery after mass extinction: evolutionary assembly in large-scale biosphere dynamics. Philosophical Transactions of the Royal Society B: Biological Sciences, 357, 697-707.

Steffen, W., Broadgate, W., Deutsch, L., Gaffney, O. \& Ludwig, C. (2015a). The trajectory of the Anthropocene: The Great Acceleration. The Anthropocene Review, 2, 81-98.

Steffen, W., Richardson, K., Rockström, J., Cornell, S.E., Fetzer, I., Bennett, E.M., Biggs, R., Carpenter, S.R., de Vries, W., de Wit, C.A., Folke, C., Gerten, D., Heinke, J., Mace, G.M., Persson, L.M., Ramanathan, V., Reyers, B. \& Sörlin, S. (2015b). Planetary boundaries: Guiding human development on a changing planet. Science, 347, 736.

Stein, A., Gerstner, K. \& Kreft, H. (2014). Environmental heterogeneity as a universal driver of species richness across taxa, biomes and spatial scales. Ecol. Lett., 17, 866-880.

Stockwell, C.A., Hendry, A.P. \& Kinnison, M.T. Contemporary evolution meets conservation biology. Trends Ecol. Evol., 18, 94-101.

Storfer, A., Murphy, M.A., Spear, S.F., Holderegger, R. \& Waits, L.P. (2010). Landscape genetics: where are we now? Molecular Ecology, 19, 3496-3514.

Struebig, M.J., Kingston, T., Petit, E.J., Le Comber, S.C., Zubaid, A., Mohd-Adnan, A. \& Rossiter, S.J. (2011). Parallel declines in species and genetic diversity in tropical forest fragments. Ecol. Lett., 14, 582-590.

Suding, K.N., Lavorel, S., Chapin, F.S., Cornelissen, J.H.C., Diaz, S., Garnier, E., Goldberg, D., Hooper, D.U., Jackson, S.T. \& Navas, M.-L. (2008). Scaling environmental change through the community-level: a trait-based response-and-effect framework for plants. Glob. Ch. Biol., 14, 1125-1140.

Terrell, K.A., Crosier, A.E., Wildt, D.E., O'Brien, S.J., Anthony, N.M., Marker, L. \& Johnson, W.E. (2016). Continued decline in genetic diversity among wild cheetahs (Acinonyx jubatus) without further loss of semen quality. Biol. Cons., 200, 192-199.

Thomas, C.D. (2013). The Anthropocene could raise biological diversity. Nature 502, 7 (doi:10.1038/502007a) Nature, 502, 7.

Thomas, C.D. (2015). Rapid acceleration of plant speciation during the Anthropocene. Trends Ecol. Evol., 30, 448-455.

Thomsen, P.F. \& Willerslev, E. (2015). Environmental DNA - An emerging tool in conservation for monitoring past and present biodiversity. Biol. Cons., 183, 4-18. 
Tigano, A. \& Friesen, V.L. (2016). Genomics of local adaptation with gene flow. Molecular Ecology, 25, 2144-2164.

Tilman, D., Clark, M., Williams, D.R., Kimmel, K., Polasky, S. \& Packer, C. (2017). Future threats to biodiversity and pathways to their prevention. Nature, 546, 73-81.

Tilman, D., Dodd, M., Silvertown, J., Poulton, P., Johnston, A. \& Crawley, M. (1994a). The park grass experiment-insights from the most long-term ecological study. In: Longterm Experiments in Agricultural and Ecological Science. Wallingford, Oxon. (eds. Leigh, RA \& Johnston, AE). CAB International Wallingford, Oxon, UK, pp. 287-303.

Tilman, D., Isbell, F. \& Cowles, J.M. (2014). Biodiversity and Ecosystem Functioning. Ann. Rev. Ecol. Evol. Syst., 45, 471-493.

Tilman, D., May, R.M., Lehman, C.L. \& Nowak, M.A. (1994b). Habitat destruction and the extinction debt. Nature, 371, 65.

Twitchett, R.J. (2006). The palaeoclimatology, palaeoecology and palaeoenvironmental analysis of mass extinction events. Palaeogeography, Palaeoclimatology, Palaeoecology, 232, 190-213.

Urban, M.C. (2015). Accelerating extinction risk from climate change. Science, 348, 571573.

van der Plas, F., Manning, P., Allan, E., Scherer-Lorenzen, M., Verheyen, K., Wirth, C., Zavala, M.A., Hector, A., Ampoorter, E., Baeten, L., Barbaro, L., Bauhus, J., Benavides, R., Benneter, A., Berthold, F., Bonal, D., Bouriaud, O., Bruelheide, H., Bussotti, F., Carnol, M., Castagneyrol, B., Charbonnier, Y., Coomes, D., Coppi, A., Bastias, C.C., Muhie Dawud, S., De Wandeler, H., Domisch, T., Finér, L., Gessler, A., Granier, A., Grossiord, C., Guyot, V., Hättenschwiler, S., Jactel, H., Jaroszewicz, B., Joly, F.-X., Jucker, T., Koricheva, J., Milligan, H., Müller, S., Muys, B., Nguyen, D., Pollastrini, M., Raulund-Rasmussen, K., Selvi, F., Stenlid, J., Valladares, F., Vesterdal, L., Zielínski, D. \& Fischer, M. (2016). Jack-of-all-trades effects drive biodiversity-ecosystem multifunctionality relationships in European forests. 7, 11109.

Vellend, M., Baeten, L., Myers-Smith, I.H., Elmendorf, S.C., Beauséjour, R., Brown, C.D., De Frenne, P., Verheyen, K. \& Wipf, S. (2013). Global meta-analysis reveals no net change in local-scale plant biodiversity over time. PNAS, 110, 19456-19459.

Vellend, M. \& Geber, M.A. (2005). Connections between species diversity and genetic diversity. Ecol. Lett., 8, 767-781. 
Villéger, S., Mason, N.W.H. \& Mouillot, D. (2008). New multidimensional functional diversity indices for a multifaceted framework in functional ecology. Ecology, 89, 2290-2301.

Wang, S. \& Loreau, M. (2014). Ecosystem stability in space: $\alpha, \beta$ and $\gamma$ variability. Ecol. Lett., 17, 891-901.

Wardle, D.A., Bardgett, R.D., Callaway, R.M. \& Van der Putten, W.H. (2011). Terrestrial Ecosystem Responses to Species Gains and Losses. Science, 332, 1273-1277.

Warren, M.S., Hill, J.K., Thomas, J.A., Asher, J., Fox, R., Huntley, B., Roy, D.B., Telfer, M.G., Jeffcoate, S., Harding, P., Jeffcoate, G., Willis, S.G., Greatorex-Davies, J.N., Moss, D. \& Thomas, C.D. (2001). Rapid responses of British butterflies to opposing forces of climate and habitat change. Nature, 414, 65-69.

Whittaker, R.H. (1972). Evolution and Measurement of Species Diversity. Taxon, 21, 213251.

Whittaker, R.H. (1977). Evolution of species diversity in land communities [Birds and vascular plants]. Evolutionary biology.

WWF (2016). Living Planet Report 2016. http://wwf.panda.org/about_our_earth/all_publications/lpr_2016/.

Yachi, S. \& Loreau, M. (1999). Biodiversity and ecosystem productivity in a fluctuating environment: The insurance hypothesis. Proceedings of the National Academy of Sciences, 96, 1463-1468. 